\title{
The importance of a seasonal ice zone and krill density in the historical abundance of humpback whale catches in the Southern Ocean
}

\author{
CÉDric CotTÉ AND Christophe Guinet \\ Centre d'Études Biologiques de Chizé, Centre National de la Recherche Scientifique, 79360 Villiers en Bois, France \\ Contacte-mail: cecotte@cebc.cnrs.fr
}

\begin{abstract}
Humpback whale populations in the Southern Hemisphere were dramatically reduced by the whaling industry. A comprehensive whaling dataset was used in an analysis of circumpolar abundance of humpback whale catches relative to contemporary densities of its preferred prey, Antarctic krill, and to a major dynamic feature of the marine ecosystem, the summer seasonal ice zone (SSIZ) derived from southernmost whaling locations. The circumpolar abundance of catches derived only from pelagic data, i.e. about $30 \%$ of the total humpback whale catches in the Southern hemisphere, was found to be only marginally related to krill density. However, the total abundance of catches - from pelagic operations and land stations, from high and low latitudes - was found to be more related to SSIZ than to krill density, especially when excluding the highly dynamic west Atlantic region where the circulation probably drives the ecosystem. A large SSIZ is likely to provide a favourable feeding ground for humpback whales, given their high energy requirements and because of its predictability and the prey aggregation processes occurring there.
\end{abstract}

KEYWORDS: HUMPBACK WHALE; SOUTHERN OCEAN; WHALING; CATCH ABUNDANCE; ICE; EUPHAUSIIDS; SOUTHERN HEMISPHERE

\section{INTRODUCTION}

The humpback whale (Megaptera novaeangliae) is the most studied whale species of the Southern Hemisphere, due to its typical seasonal migration between winter breeding grounds in tropical/sub-tropical areas and summer feeding grounds in Antarctic waters (e.g. Paton and Clapham, 2006; Stevick et al., 2004; Zerbini et al., 2006). In contrast with other large balaenopterids, humpback whales breed in delimited coastal breeding grounds, which has resulted in the identification of seven geographically defined stocks (IWC, 1998; Rice, 1998), each associated with supposed feeding grounds (Donovan, 1991; IWC, 1998). The predictability and the availability of humpback whales has made them accessible to the modern whaling industry since the beginning of the $20^{\text {th }}$ century, before the exploitation of the larger baleen whales such as blue and fin whales (Brown and Lockyer, 1984), and until the cessation of humpback whaling in the Southern Hemisphere in 1963 (although the Soviet whaling fleet was active until 1973). Based on catch records corrected for illegal Soviet whaling, a total of more than 200,000 humpback whales was killed in the Southern Hemisphere from 1904 to 1980 (Clapham and Baker, 2001).

Tynan (1998) suggested that the heterogeneous distribution exhibited by the higher trophic-level populations in the marine environment, including whales, is influenced by the Southern Boundary of the Antarctic Circumpolar Current. She suggested that the circumpolar distribution of whales reflects the non-uniform high-latitude penetration of the typical water mass of the Antarctic circumpolar current. Sea ice has also been recognized as a major driving force of the Southern Ocean, playing a crucial role in primary production and also in population dynamics and recruitment of Antarctic krill (Atkinson et al., 2004; Loeb et al., 1997), the chief prey of humpback whales (Kawamura, 1994; Laws, 1977). Indeed sea ice seems to be important for large krilleating whales (Nicol et al., 2000; Thiele et al., 2000) since the pelagic whaling industry was created to catch whales at the ice edge where both whales and krill concentrate
(Brierley et al., 2002). In this paper the relationship between sea ice extent, available estimates of krill density, and the abundance of humpback whale catches longitudinally in the Antarctic, is investigated.

\section{MATERIALS AND METHODS}

Whales, krill and environmental data

Whaling catch data were provided by the International Whaling Commission (IWC). Humpback whale catch data from industrial floating factory operations in the Southern Ocean from 1913 to 1973 (including Soviet catches) were calculated. Catches from land stations, taken early in the $20^{\text {th }}$ century, were also considered. Land station catches from colder waters (south of $40^{\circ} \mathrm{S}$ latitude including data from South Georgia and the South Shetland Islands), and land station catches in waters north of $40^{\circ} \mathrm{S}$ latitude (including data from Southern Africa, America, Australia and New Zealand) were pooled. The IWC has recognised that catch allocation to breeding/feeding ground is important because it has to take into account mixing of two or more stocks. The extent of the problem varies with feeding area and breeding stock. For the circumpolar analyses, catches from land stations and from low latitudes (i.e. breeding grounds) were allocated to the corresponding feeding grounds in the Southern Ocean according to known migration patterns between breeding and feeding grounds and stock structure models developed by IWC (2005). These were established from documented connections using several methods such as returns of Discovery tags, photo-identification and genetic marks, or satellite tracking (Chittleborough, 1965; Mackintosh, 1942; Pomilla and Rosenbaum, 2005; Zerbini et al., 2006). Total catches in each breeding area were divided by the number of $10^{\circ}$ sectors and allocated equally among them according to available information on migration patterns. For cases where connections were uncertain, a weighted allocation of catches was used (e.g. the updated 'Fringe' models proposed in IWC (2006) when two 
neighbouring areas are likely to overlap) to provide for suitable examination of the effect of uncertainty in catch allocation on assessments. The weighted allocation taking this uncertainty into account was calculated such that for the $10^{\circ}$ sectors corresponding to 'fringes', half of the catches from land stations and breeding grounds were attributed to each of the two putatively overlapping feeding areas.

Hjort et al. (1933) introduced the concept of 'catch per boat per day' and used the expression 'catcher's days work' in measuring effort. Omura (1973) summed effort from 1931 to 1972 by $10^{\circ}$ squares of latitude and longitude. In this paper effort has been summed for the same $10^{\circ}$ longitude squares to estimate circumpolar effort over the pelagic whaling period (1931 to 1972) although it should be noted that whaling was banned in the sector between $70^{\circ} \mathrm{W}$ and $160^{\circ} \mathrm{W}$ in 1938 and again in 1947-1955, and permitted for only four days each season in the 1950s.

Sea ice extent was derived from the whaling catch data for each month from December to February and averaged over the 1931-1960 period. From 1904 to 1930 whales were taken in areas surrounding land stations, for which there is no information on sea ice extent. From 1931, the location of the ice edge, where the pelagic fleets concentrated their effort, was calculated as the mean latitude of the southernmost catch positions of all large whale species (more details are given in Cotté and Guinet, 2007). Thus, only pelagic catcher data were used in this historical definition of sea ice extent. The mean latitudes of the 10 southernmost whale catch positions were calculated for $36 \times 10^{\circ}$ longitudinal circum-Antarctic sectors; for a given sector, month and year, catch positions more than $3^{\circ}$ north of the southernmost catch position were excluded. Across all years, the mean summer seasonal ice zone (SSIZ) was defined as the area delimited by the maximum summer (December) and the minimum summer (February) sea ice extent (Parkinson, 2004).

Global estimates of krill biomass were extracted from the compilation by Atkinson et al. (2004) of historical krill densities in the Southern Ocean. These data were derived from the Discovery expeditions (Foxton, 1966; Marr, 1962), during the summers of 1926-39. They were obtained from archived net sampling logs, original tables and an electronic krill database. Most of the Discovery net samplings were carried out with a $1 \mathrm{~m}$ ringnet.

\section{Data analysis}

The Southern Ocean was divided into 36 sectors of $10^{\circ}$ where the longitudinal abundance of whale catches, krill density and SSIZ were averaged. This sector size corresponds to the longitudinal resolution of sea ice extent from the analysis of Cotté and Guinet (2007). Generalised Additive Model (GAM, Hastie and Tibshirani, 1990) analysis was used to investigate relationships, possibly nonlinear, between SSIZ and krill densities and the longitudinal variability of whale catches. In order to take into account the

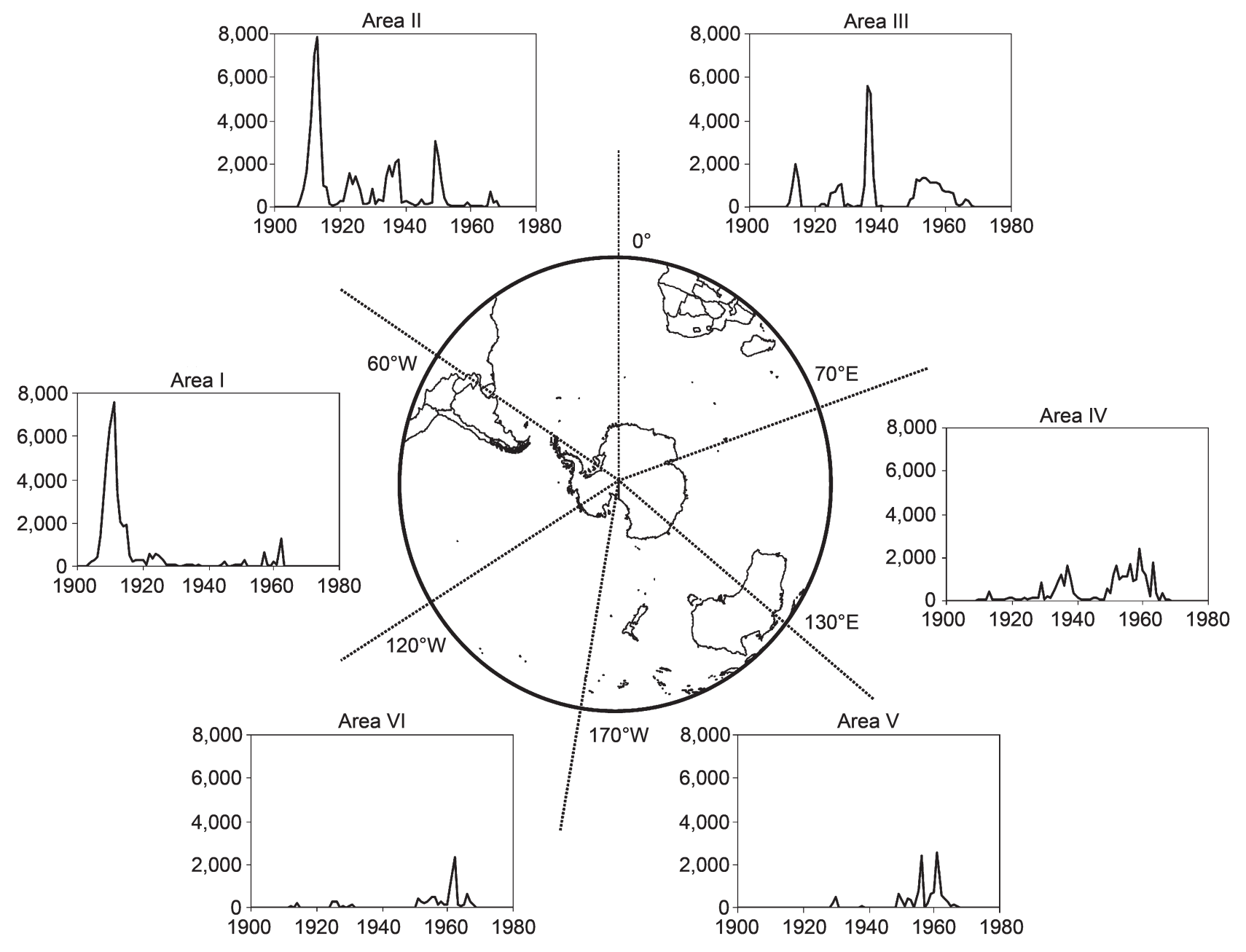

Fig. 1. Total catches for the six areas (IWC, 2006) of the Southern Hemisphere. 
spatial structure of the catches, an autocorrelation term was added to the model:

$$
\begin{aligned}
\text { Catch abundance } & =\beta_{0}+\mathrm{s}(\mathrm{SSIZ})+\mathrm{s}(\text { krill densities }) \\
& +\mathrm{s}(\text { autocorrelation })
\end{aligned}
$$

Since data were not normally distributed (Shapiro-Wilk tests, all $P<0.05$ ), a log-link function and a negative binomial distribution were used.

The analysis was first performed with pelagic whaling data only. Subsequently analyses were carried out with the land station data included in the catch dataset. Further analysis excluded the sectors from the Antarctic Peninsula to the South Sandwich Islands, i.e. between $75^{\circ} \mathrm{E}$ and $15^{\circ} \mathrm{E}$, where an advection process is suspected to be the main factor driving krill and whale distribution (Trathan et al., 2007). Indeed, the krill population in the West Southwest Atlantic area has been shown to be especially driven by advection, where the process is known as the 'krill conveyor belt' (Fach and Klinck, 2006; Murphy et al., 1998).

\section{RESULTS}

Circumpolar exploitation of humpback whales occurred over approximately six decades, from the beginning of the $20^{\text {th }}$ century until the 1960s. Fig. 1 shows intensive early exploitation in Areas I and II prior to the introduction of pelagic operations. Whaling occurred throughout the period for Areas II and III, with later exploitation in Areas IV, V and VI. Population productivity should be thus taken into consideration in areas where catches are lower but extend over a longer period. Despite lack of knowledge of the rate of productivity of circumpolar humpback whale populations (varying with population level), it could be reasonably suggested that this productivity is well below total catch levels during this intensive whaling period.

Whaling effort, represented as 'catcher's day's work' (Fig. 2 ), reveals a heterogeneous circumpolar pattern, with considerably more time spent in the Atlantic and Indian Oceans than in the Pacific. Such differences could be attributed to the cessation of whaling in Pacific waters for about ten years. However, effort south of the eastern Australian and Kerguelen-Heard regions was similar, despite a lack of regulation. Regulation is thus not the main driver of the effort pattern. Indeed, the pattern is very similar to that for catches (Figs 3 and 4). Moreover, the reason why this parameter was not used to explain catch abundance is that the main targets of pelagic whaling driving the effort pattern were blue and fin whales rather than humpback whales.

The SSIZ is large in the east Atlantic and west Indian sector and north of the Ross Sea (Fig. 3b). Krill were abundant in the Atlantic Ocean and also in the East-Indian sector, i.e. around $90^{\circ} \mathrm{E}$ (Fig. 3c). Circumpolar catch abundance from pelagic whaling in the Southern Ocean also exhibited a marked heterogeneous circumpolar pattern (Figs

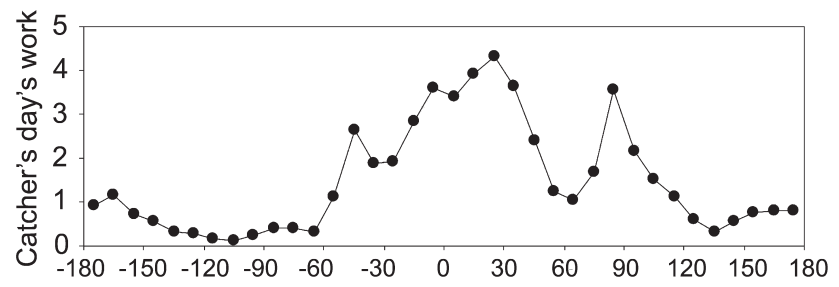

Fig. 2. Longitudinal pelagic whaling effort, summed from 1931 to 1972, as 'catcher's days work' (from Omura, 1973) 3a, 4b). Most catches were in the West Atlantic and East Indian sectors, in the Ross Sea, and south of South Africa. The addition of land station data from polar waters incorporated catches mainly from the southwestern Atlantic, while land station data in subtropical/tropical waters increased the catch data available mainly between $15^{\circ} \mathrm{W}$ and $180^{\circ} \mathrm{W}$, i.e. in the African and Australian sectors (Fig. 4c).

The GAM analyses showed that circum-Antarctic krill densities were not associated with SSIZ $(P=0.45)$. Since they are statistically independent, these two explanatory variables were included in the models (Table 1). Catch distribution from pelagic data was explained only partially by krill densities. Circumpolar catch abundance in the Southern Hemisphere (from pelagic and land station data), was related to SSIZ. Excluding western Atlantic sectors (between $75^{\circ} \mathrm{E}$ and $15^{\circ} \mathrm{E}$ ), krill densities were still not associated with SSIZ $(P=0.15)$ and SSIZ is the major explanatory variable for the longitudinal abundance of humpback catches. Using large longitudinal sectors of $30^{\circ}$ no relationship was obtained for pelagic data only when the total circumpolar catches of whales was linked to both krill and SSIZ, either when including the West Atlantic area (krill and SSIZ, $P<0.01)$ or excluding the West Atlantic area $(P=$ $0.01)$.

\section{DISCUSSION}

Several biases occurred when attempting to quantify proxies for humpback whale circumpolar abundance such as whaling effort, rate of productivity and regulation of catches (spatially, in the western Pacific from $70^{\circ}$ to $160^{\circ} \mathrm{W}$ in 1939 and from 1948 to 1955 , and temporally such as the four day season in the 1950s). Despite these biases, pelagic catches taken in the Southern Ocean are the most relevant data for approximation of circumpolar abundance of humpback whales. However, pelagic whaling constituted only $30 \%$ of the total humpback whaling conducted and it was thus necessary to add the large amount of low latitude catches and data from high latitude land station to provide a more realistic assessment of the circumpolar abundance of humpback whales. This was particularly the case for Areas I and II where most whales were caught prior to pelagic whaling (1930). The assessment relies upon knowledge of the migration pattern of humpback whales between breeding and feeding grounds in order so as to correctly allocate catches from low latitudes. Some connections, for example between Breeding Stock A off Brazil and feeding grounds in Area II, are now relatively well understood through satellite tracking, confirming the feeding ground from the Antarctic Peninsula to the South Sandwich Islands (Zerbini et al., 2006), although Discovery marks show that whales can cross the Drake passage (Paton and Clapham, 2006). Uncertainties still exist over the specific migratory destinations of some populations and care needs to be taken when allocating breeding ground catches by feeding areas. Despite migration corridors in a relatively straight north-south line, the humpback whale has been shown to be a mobile species possibly travelling longitudinally to extended feeding grounds and limited breeding grounds see IWC (2005; 2006). The hypothesis of discrete groups in relation to Southern Hemisphere stock structure (Mackintosh, 1942) is supported by Discovery mark data, suggesting relatively discrete longitudinal fidelity and low incidence of large scale movement between areas. Furthermore, as total catch is only a proxy measure of abundance and does not give absolute abundance, it is important to take into account how long the 


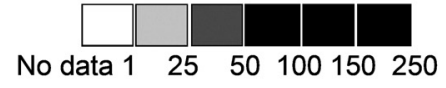

(a)
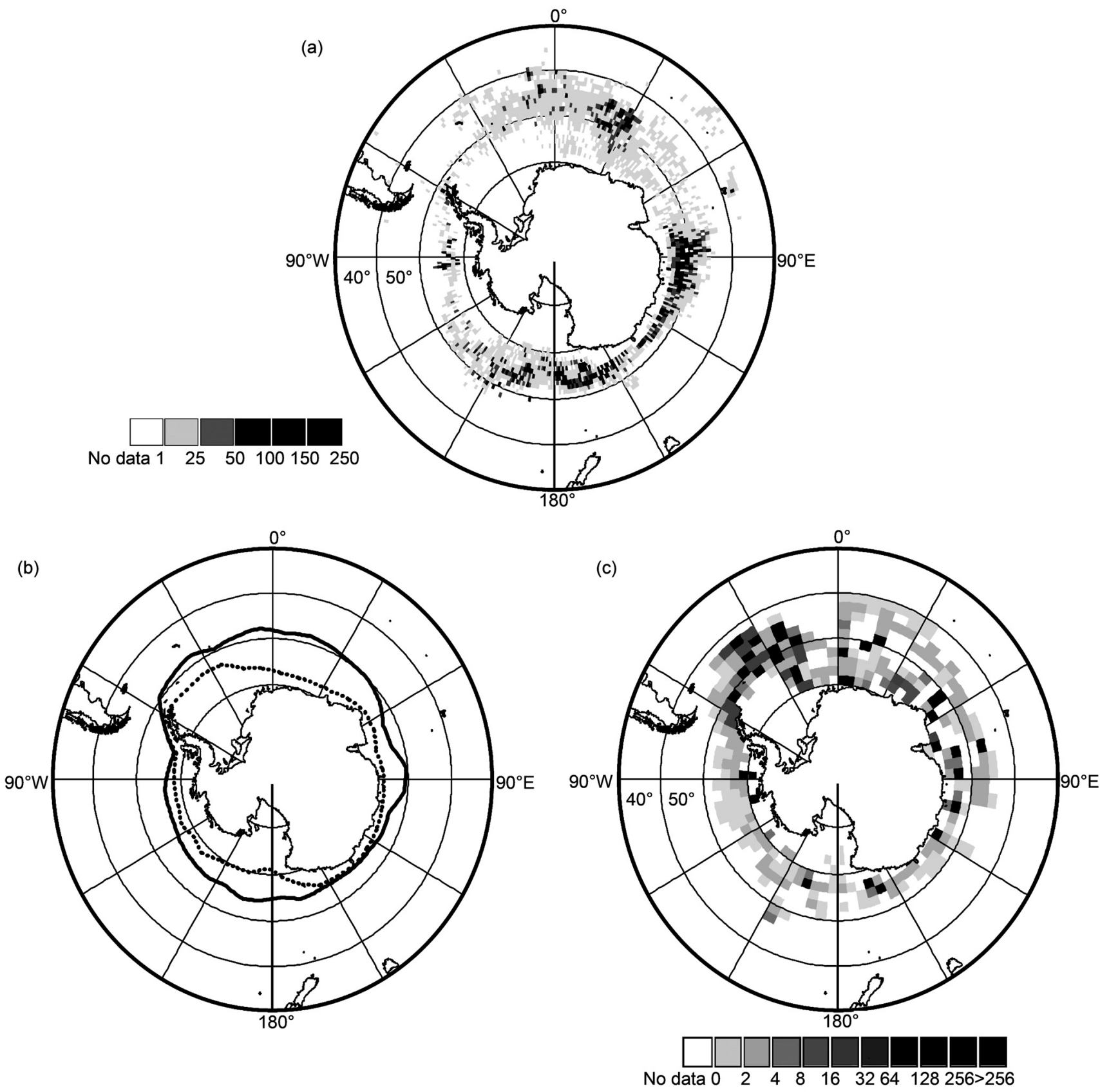

Fig. 3. Whales, SSIZ and krill distribution. (a) Pelagic catches. (b) Early (December, continuous line) and late (February, dotted line) summer ice extent. (c) Global krill distribution (number of krill per $\mathrm{m}^{-2}$ ) (from Atkinson et al., 2004)

catches were taken for and the level of final depletion. It is difficult to assess this level on a stock by stock basis and, while there is currently an increase in humpback whale abundance in several areas, post-whaling abundance from the 1970s suggests that a large proportion of the total whale population was caught. Areas with exploitation spread over a period of time, such as Areas II and III, can exhibit some recovery in numbers, while short and intense exploitation gives a snapshot of the situation. Although some recovery could lead to an overestimate of the abundance of humpback whales where exploitation was consistently spread over time, it can be assumed that 'whale production' is less than total catches, especially in Areas II and III, and thus should not influence the analysis.

From pelagic catch records, the east Indian and south African sectors exhibit high humpback whale abundance, while land station data from the southern feeding grounds add many catches, mainly in the Atlantic sector where humpback whaling began owing to the accessibility of animals close to islands. The whole pattern, reconstructed from pelagic, southern (feeding) land stations and northern (breeding) catches, is very similar to the circumpolar patterns of blue and fin whale catches (Branch et al., 2007). The slight relationship between catch abundance from pelagic data only and krill density does not seem to be reliable since the circumpolar abundance of whale catches is largely underestimated, particularly in the sector from the west Atlantic to the west Indian Ocean. In considering the circumpolar abundance of all catches, SSIZ is the dominant parameter, especially when the southwest Atlantic sector is excluded. Indeed the increase of the SSIZ in explaining whale catch abundance when excluding this area, where high densities of krill were reported, shows that this parameter is especially important in the other areas. On the basis that 

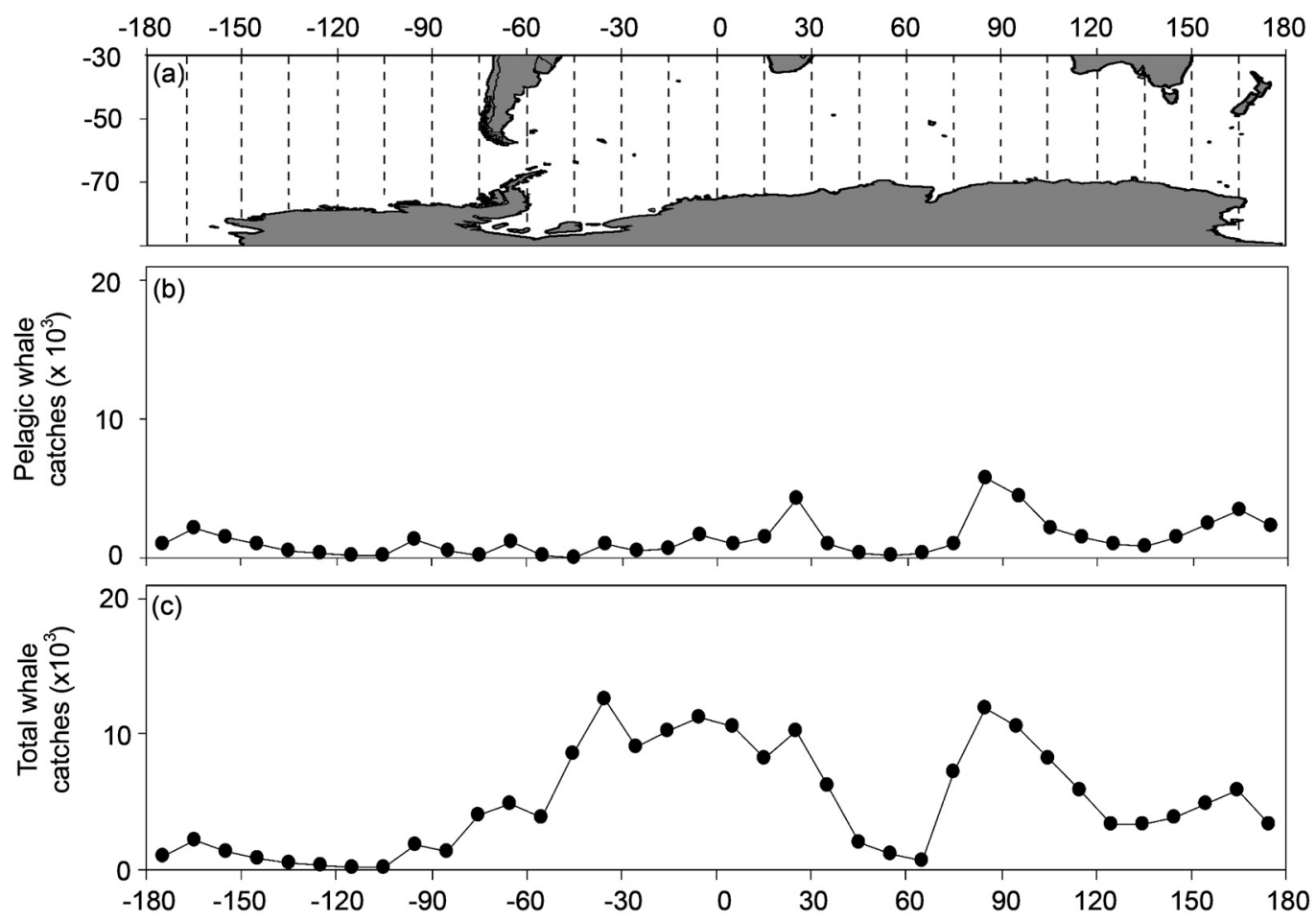

Fig. 4. (a) Study area. (b) Circumpolar abundance of whales from pelagic catches. (c) Circumpolar abundance of whales from pelagic and land station data. Catches from high latitude land stations were allocated to longitudinal sectors according to known migration patterns between breeding and feeding grounds and stock structure.

longitudinal movements within each stock (Paton and Clapham, 2006) could confuse the analysis, i.e. catches would be more representative of whaling effort than a proxy of whale abundance, the same analysis was done at a coarser scale using $30^{\circ}$ sectors. Although whale catch abundance was correlated with both krill densities and SSIZ, the results using $10^{\circ}$ and $30^{\circ}$ seem to be relatively robust to any noise in the analysis resulting from possible movements.

The marginal relationship with krill in the $10^{\circ}$ sector analysis may be influenced by the strong densities of both whale catches and krill in the west Atlantic sector. This region is highly dynamic and krill distribution and abundance are believed to be driven by the complex circulation between the Antarctic Peninsula (corresponding to Area I), and South Georgia (corresponding to Area II) (Murphy et al., 1998). However, circumpolar catch abundance is more definitely related to the large SSIZ from the east Atlantic to west Indian Ocean and in the eastern Indian Ocean. As the humpback whale is one of the largest krill predators in the Southern Ocean, undertaking long migrations to consume large amounts of krill, it was not expected that whale catch abundance would be less related to krill than to the SSIZ. Such a result could be either an artefact due to the lack of an accurate assessment at a circumpolar scale (Smetacek and Nicol, 2005), or reflect the importance of SSIZ in affecting krill biomass and thus the accessibility of these prey to whales feeding in the vicinity of the sea-ice edge.

The results in relation to the SSIZ suggest that humpback whales mainly targeted krill in relation to sea-ice habitat, and not simply in relation to the overall prey abundance. Whales are known to follow the receding ice edge, followed by the whaling fleets (Hjort et al., 1933), where large densities of krill could be found. Indeed, abundant krill were found just south of the ice edge (Brierley et al., 2002). Although krill are able to track the receding ice edge, the rapid melting of pack ice through summer removes this protective shield from air-breathing predators (Lizotte, 2001). Krill are then available in large and dense swarms allowing highly efficient foraging by large whales (Nemoto, 1970). However, rich aggregations of krill are of little interest for whales if they are not autocorrelated in time and space (Simard and Lavoie, 1999). The patchiness of whale prey could therefore be a key factor for the attractiveness of the Antarctic area, with the SSIZ acting as a major predictable feature influencing krill abundance and distribution. A large SSIZ ensures an efficient

Table 1

Results of the GAM analyses of summer seasonal ice zone (SSIZ), and krill explaining the variability of the different datasets of southern humpback whale catch abundance.

\begin{tabular}{lcrrr}
\hline & Explanatory variables & $F$ & $d f$ & $P$ \\
\hline Pelagic data & SSIZ & 2.58 & 1 & 0.12 \\
& Krill & 3.03 & 1.78 & 0.06 \\
Total circumpolar data & SSIZ & 4.17 & 1 & 0.05 \\
& Krill & 2.03 & 1.61 & 0.15 \\
Circumpolar data without western Atlantic sectors & SSIZ & 13.87 & 1 & $<0.01$ \\
& Krill & 2.75 & 1 & 0.11 \\
\hline
\end{tabular}


feeding ground as the ice sheet decays over summer. The sea ice habitat is important for krill, especially because of sea ice algae, which provide the only suitable food for krill larvae, the most sensitive feeding stage in the krill life cycle (Ross et al., 2000).

\section{ACKNOWLEDGEMENTS}

We thank the IWC (G. Donovan and C. Allison) for providing the database. We also acknowledge the Soviet scientists who collected and provided the revised Soviet data, A. Zerbini and K. Findlay for their helpful comments and C. Barbraud and F. Samaran for helping in data analysis. Comments from two anonymous reviewers substantially improved the paper. This study was carried out in the framework of GICC programs.

\section{REFERENCES}

Atkinson, A., Siegel, V., Pakhomov, E. and Rothery, P. 2004. Long-term decline in krill stock and increase in salps within the Southern Ocean. Nature 432: 100-03.

Branch, T.A., Stafford, K.M., Palacios, D.M., Allison, C., Bannister, J.L., Burton, C.L.K., Cabrera, E., Carlston, C.A., Galletti Vernazzani, B., Gill, P.C., Hucke-Gaete, R., Jenner, K.C.S., Jenner, M., Matsuoka, K., Mikhalev, Y., Miyashita, T., Morrice, M., Nishiwaki, S., Sturrock, V.J., Tormosov, D., Anderson, R.C., Baker, A.N., Best, P.B., Borsa, P., Brownell, R.L., Childerhouse, S., Findlay, K., Gerrodette, T., Ilangakoon, A.D., Joergensen, M., Kahn, D.K., Ljungblad, B., Maughan, B., McCauley, R.D., McKay, S., Norris, T.F., Rankin, S., Samaran, F., Thiele, D., Van Waerebeek, K. and Warneke, R.M. 2007. Past and present distribution, densities and movements of blue whales in the Southern Hemisphere and northern Indian Ocean. Mammal Rev. 37(2): 116-75.

Brierley, A.S., Fernandes, P.G., Brandon, M.A., Armstrong, F., Millard, N.W., McPhail, S.D., Stevenson, P., Pebody, M., Perret, J., Squires, M., Bone, D.G. and Griffiths, G. 2002. Antarctic krill under sea ice: elevated abundance in narrow band just south of ice edge. Science 295: $1,890-1,92$.

Brown, S.G. and Lockyer, C.H. 1984. Whales. pp.717-81. In: Laws, R.M. (eds). Antarctic Ecology. Academic Press, London. 998pp.

Chittleborough, R.G. 1965. Dynamics of two populations of the humpback whale, Megaptera novaeangliae (Borowski). Aust. J. Mar. Freshwater Res. 16(1): 33-128.

Clapham, P.J. and Baker, C.S. 2001. Modern whaling. pp.1328-32. In: Perrin, W.F., Würsig, B. and Thewissen, J.G.M. (eds). Encylopedia of Marine Mammals. Academic Press, New York.

Cotté, C. and Guinet, C. 2007. Historical whaling records reveal major regional retreat of Antarctic sea ice. Deep-Sea Research I 54: 243-52.

Donovan, G.P. 1991. A review of IWC stock boundaries. Rep. int. Whal. Commn (special issue) 13: 39-68.

Fach, B.A. and Klinck, J.M. 2006. Transport of Antarctic krill (Euphausia superba) across the Scotia Sea. Part I: circulation an particle tracking simulations. Deep-Sea Res. I 53: 987-1010.

Foxton, P. 1966. The distribution and life-history of Salpa thompsoni Foxton with observations on a related species, Salpa gerlachei Foxton. Discovery Rep. XXXIV: 1-116.

Hastie, T.J. and Tibshirani, R.J. 1990. Generalized Additive Models. 43 vols, Monographs on Statistics and Applied Probability. Chapman and Hall, London. 335pp.

Hjort, J., Lie, J. and Ruud, J.T. 1933. Norwegian pelagic whaling in the Antarctic. III. The season 1932-33. Hvalrådets Skrifter 8: 1-36+2pls.

International Whaling Commission. 1998. Report of the Scientific Committee. Annex G. Report of the sub-committee on Comprehensive Assessment of Southern Hemisphere humpback whales. Rep. int. Whal. Commn 48:170-82.

International Whaling Commission. 2005. Report of the Scientific Committee. Annex H. Report of the sub-committee on other Southern Hemisphere whale stocks. J. Cetacean Res. Manage. (Suppl.) 7:235-44.
International Whaling Commission. 2006. Report of the Scientific Committee. Annex H. Report of the Sub-Committee on the Other Southern Hemisphere Whale Stocks. J. Cetacean Res. Manage. (Suppl.) 8:151-70.

Kawamura, A. 1994. A review of baleen whale feeding in the Southern Ocean. Rep. int. Whal. Commn 44: 261-72.

Laws, R.M. 1977. Seals and whales of the southern ocean. Philos. Trans. R. Soc. Lond. B. (Biol. Sci.) 279: 81-96.

Lizotte, M.P. 2001. The contributions of sea ice algae to Antarctic Marine Primary Production. American Zoology 41: 57-73.

Loeb, V., Siegal, V., Holm-Hansen, O., Hewitt, R., Fraser, W., Trivelpiece, W. and Trivelpiece, S. 1997. Effects of sea ice extent and krill or salpa dominance on the Antarctic food web. Nature 387: 897-900.

Mackintosh, N.A. 1942. The southern stocks of whalebone whales. Discovery Rep. 22: 197-300.

Marr, J.W.S. 1962. The natural history and geography of the Antarctic krill (Euphausia superba Dana). Discovery Rep. 32(2): 33-464.

Murphy, E.J., Watkins, J.L., Reid, K., Trathan, P.N., Everson, I., Croxall, J.P., Priddle, J., Brandon, M.A., Brierley, A.S. and Hofmann, E. 1998. Interannual variability of the South Georgia marine ecosystem, biological and physical sources of variation in the abundance of krill. Fisheries Oceanography 7: 381-90.

Nemoto, T. 1970. Feeding pattern of baleen whales in the ocean. pp.241-52. In: Steele, J.H. (eds). Marine Food Chains. Oliver and Boyd, Edinburgh. 552pp.

Nicol, S., Pauly, T., Bindoff, N.L., Wright, S., Thiele, D., Hosie, G.W., Strutton, P.G. and Woehler, E. 2000. Ocean circulation off east Antarctic affects ecosystem structure and sea-ice extent. Nature 406: 504-07.

Omura, H. 1973. A review of pelagic whaling operations in the Antarctic based on the effort and catch data in $10^{\circ}$ squares of latitude and longitude. Sci. Rep. Whales Res. Inst., Tokyo 25: 105-203.

Parkinson, C.L. 2004. Southern Ocean sea ice and its wider linkages: insights revealed from models and observations. Antarct. Sci. 16(4): 387-400.

Paton, D.A. and Clapham, P.J. 2006. An assessment of Southern Hemisphere humpback whale population structure and migratory interchange based on Discovery mark data. Paper SC/A06/HW33 presented to the IWC Workshop on Comprehensive Assessment of Southern Hemisphere Humpback Whales, Hobart, Tasmania, 3-7 April 2006 (unpublished). 19pp. [Paper available from the Office of this Journal].

Pomilla, C. and Rosenbaum, H.C. 2005. Against the current: an interoceanic whale migration event. Biology Letters 2005(1): 476-79.

Rice, D.W. 1998. Marine Mammals of the World: Systematics and Distribution, Special Publication Number 4, The Society for Marine Mammalogy. Allen Press, USA. ix+231pp.

Ross, R.M., Quetin, L.B., Baker, K.S., Vernet, M. and Smith, R.C. 2000. Growth limitation in young Euphausia superba under field conditions. Limnol. Oceanogr. 45: 31-43.

Simard, Y. and Lavoie, D. 1999. The rich krill aggregation of the SaguenaySt. Lawrence Marine Park, hydroacoustics and geostatistical biomass estimates, structure, variability and significance for whales. Can. J. Fish. Aquat. Sci. 56: 1,182-1,97.

Smetacek, V. and Nicol, S. 2005. Polar ocean ecosystems in a changing world. Nature 437: 362-88.

Stevick, P.T., Aguayo, A., Allen, J., Avila, I.C., Capella, J., Castro, C., Chater, K., Dalla Rosa, L., Engel, M.H., Felix, F., Florez-Gonzalez, L., Freitas, A., Haase, B., Llano, M., Lodi, L., Munoz, E., Olavarria, C., Secchi, E., Scheidat, M. and Siciliano, S. 2004. Migrations of individually identified humpback whales between the Antarctic peninsula and South America. J. Cetacean Res. Manage. 6(2): 109-13.

Thiele, D., Chester, E.T. and Gill, P.C. 2000. Cetacean distribution off Eastern Antarctica $\left(80-150^{\circ} \mathrm{E}\right)$ during the austral summer of 1995/96. Deep-Sea Res. II 47: 2,543-2,72.

Trathan, P.N., Forcada, J. and Murphy, E.J. 2007. Environmental forcing and Southern Ocean marine predator populations: effects of climate change and variability. Phil. Trans. R. Soc. B. Biological Sciences 362: 2351-65.

Zerbini, A.N., Andriolo, A., Heide-Jørgensen, M.P., Pizzorno, J.L., Maia, Y.G., VanBlaricom, G.R., DeMaster, D.P., Simões-Lopes, P.C., Moreira, S. and Bethlem, C. 2006. Satellite-monitored movements of humpback whales (Megaptera novaeangliae) in the Southwest Atlantic Ocean. Marine Ecology. Progress Series 313: 295-304. 